\title{
Adaptaciones LIJ de Tirant lo Blanc*
}

\section{Tirant lo Blanc adaptations for Children's and Young Literature}

\author{
Lluís Ramon i Ferrer \\ lluisrafe@gmail.com \\ UCV San Vicente Mártir
}

\begin{abstract}
Resumen: En este trabajo se analizan las adaptaciones de Tirant lo Blanc a la narrativa infantil y juvenil. Han quedado excluidas aquellas obras que no han considerado la novela en su totalidad así como otros géneros que también han pretendido que la obra de Martorell llegara a un público infantil y juvenil. En primer lugar, se ha establecido el corpus de estudio y, seguidamente, se ha elaborado un catalálogo en el cual se valoran la selección de secuencias del hipotexto verbal, los elementos paratextuales que han concurrido en cada uno de los volúmenes, así como la adecuación al tramo lector al que supuestamente va dirigida la publicación.
\end{abstract}

Palabras clave: Tirant lo Blanch, adaptaciones, clásicos en la literatura infantil y juvenil

Abstract: This paper analyses Tirant lo Blanc narrative adaptations on Children's and Young Adults Literature. The works which have not considered the novel as a whole have been excluded, as well as other genres which have also wanted to adapt Martorell's work for the same audience. The study begins by establishing the corpus of the books. Then, a catalogue has been made in order to assess the hypotext sequences selection, the paratextual elements within each of the volumes, and the adaptation adequacy of the contents of the books to the target reader

Keywords: Tirant lo Blanch, adaptations, classic literature for children and young

\footnotetext{
* Este trabajo se inscribe en el proyecto, "La cultura literaria medieval y moderna en la tradición manuscrita e impresa (V)”, FFI2013-45931-P, financiado por la Dirección General de Investigación del MINECO.
} 
No parece casual que el instituto dedicado a la enseñanza del catalán en el mundo entero haya venido en llamarse Ramon Llull, del mismo modo se eligieron los nombres de Cervantes, Goethe o Leopardi como símbolos culturales para los centros dedicados a la enseñanza de sus respectivos idiomas. Toda comunidad lingüística acepta y hace suyos una serie de símbolos con los que se identifica y singulariza. Los clásicos literarios forman parte esencial de esta simbología. Por tanto, si algunos personajes de la historia literaria se han convertido en emblemas de la cultura en la que los escolares están inmersos, es necesario crear vías de aproximación entre los educandos y los clásicos.

Es evidente la dificultad de acceso que presentan muchos de nuestros libros a quienes se encuentran en los primeros estadios de su formación lingüística y literaria. Ahora bien, las variantes léxicas o sintácticas propias de la época en la que fueron escritos no pueden convertirse en impedimento para la comprensión de nuestro legado cultural. Renunciar a ellos conllevaría un empobrecimiento indiscutible de la cultura del individuo y, por tanto, del conjunto de la sociedad.

Las puertas de los clásicos tienen que abrirse al público infantil eliminando los elementos que pudiesen inducir a la identificación de lectura y castigo. Facilitar la lectura supone actualizar el léxico, mitigar la dureza sintáctica, eliminar todos los aditamentos incomprensibles para el grado de formación estética del receptor. En una palabra: generar adaptaciones de los clásicos teniendo en cuenta las circunstancias formativas del receptor.

Tratar de valorar las adaptaciones LIJ de Tirant lo Blanc, nos obliga en primer lugar a establecer un marco teórico en cuanto a la definición del concepto adaptación. El Diccionario de términos literarios de Estébanez (1995:18) define esta voz como «un cambio introducido en la configuración de un texto verbal para acomodarlo a un nuevo destinatario o para acoplarlo a un género literario distinto de aquel en que originariamente se escribió.»

Esta definición, a pesar de su rotundidad, no nos proporciona los suficientes matices para valorar ediciones orientadas a un público infantil y juvenil. Marc Soriano (1995, 35-42) dice: «adaptar para los niños un libro que no les estaba destinado significa someterlo a una cantidad de modificaciones -por lo general, cortes y cercenamientos- que lo convierten en un producto que se corresponda con los intereses y el grado de comprensión de los menores, es decir, que lo vuelva asequible a este público nuevo.»

Continua diciendo Soriano: «la adaptación, sin duda, facilita el esfuerzo del joven lector, pero al mismo tiempo, puede acostumbrarlo a la pasividad. ¿Podrá, más adelante, encarar el esfuerzo de leer en su versión completa una obra que creyó -equivocadamente- que ya conocía? ¿No sería mejor esperar algunos meses o algunos años más y ofrecerle luego el texto verbal íntegro?»

Es general la agradable experiencia de contar cuentos a un niño. Una vez oído el relato, los párvulos se convierten en un público severo que no consiente que se les cambie ni un ápice de aquello que escucharon con deleite. Aquí está implícito un anhelo del ser humano: mantener inamovibles sus referentes. Una adaptación es un proceso, intencionado, de alteración de una obra literaria buscando 
unos nuevo receptores y una manera diferente de lectura. (Hutcheon, 2006) En una adaptación, lógicamente, es indispensable seleccionar; pero también lo es hacerlo con tino para mantener la unidad de la obra; hay, además, que eliminar la dificultad del texto verbal y, sin embargo, no se debe cambiar su contenido. Suavizar algunos pasajes, quitar la hondura de otros, pero no modificar su papel en la obra. (Navarro, 2006)

La elección de Tirant lo Blanc ha venido motivada no sólo por las múltiples adaptaciones LIJ que se han realizado de la obra, sino sobre todo porque esta novela transciende la simple narración de caballerías para ofrecernos el universo y la cultura del hombre medieval. Aunque esta novela fuese desconocida para nosotros, solamente el elevado número de adaptaciones que sobre ella se han hecho, nos haría sospechar que estamos ante una obra de inmenso calado. Su autor, Joanot Martorell, nos legó una obra riquísima, presentándonos la figura de un héroe que, lógicamente, muestra el deseo utópico del mismo Martorell: conseguir la liberación de Constantinopla de manos de los turcos y anexionar todo el Mediterráneo a la Cristiandad.

Muchos son los editores que han adaptado la novela de Joanot Martorell. Las publicaciones son tantas como las opiniones sobre la adaptación de los clásicos a los diferentes públicos. Algunas ediciones son anotadas manteniendo total fidelidad a los incunables, otras han adaptado la ortografía a las normas actuales del IEC y otras, además de la adaptación lingüística, han cercenado la obra por donde el adaptador moderno ha creído conveniente.

Obviamente, la adaptación supone que el hipotexto verbal queda manipulado en su estructura y en su contenido por ampliación o disminución. Genette (1989) distingue tres formas básicas de reducir una obra: eliminando partes - implica seleccionar unas partes y prescindir de otras - sintetizando la obra - mantiene todas las partes significativas del hipotexto verbal convenientemente resumidas y con interpolaciones necesarias- y, finalmente, condensando — cuando el hipotexto verbal queda convertido en un resumen.

Dado que la tarea podría desbordar nuestros intereses iniciales, hemos acotado nuestro estudio a aquellas obras LIJ que siguiesen el segundo tipo de adaptación postulado por Genette y se inclinaran por la obra de Martorell en su conjunto: Tirant en Inglaterra, en Sicilia y Rodas, en el imperio griego, en el Norte de África y, finalmente, la liberación del Imperio Griego y muerte de Tirant. Así mismo, se han dejado de lado otros géneros que también han pretendido que la obra llegara a un público infantil y juvenil.

\section{Catálogo de las adaptaciones LIJ de Tirant lo Blanc}

Para la selección de las obras hemos recurrido al catálogo de ISBN, donde hemos topado con que los intereses editoriales han urdido una tupida telaraña de ediciones y reimpresiones que, aunque no quedan reflejadas en este trabajo, no por ello hemos dejado de constatar. Ciñéndonos a las LIJ, 
y sin ánimo de exhaustividad, hemos localizado adaptaciones teatrales, ${ }^{1}$ adaptacions en còmic, ${ }^{2}$ adaptaciones parciales de la obra, y, finalmente las siguientes adaptaciones LIJ de la obra completa y en un solo volumen:

1.1. Martorell, J. (1979) Tirant el Blanc. Adaptació per a nois i noies, Joan Sales adapt; Ferran Solde vila prol; Elvira Elías ilustr; Edicions del Mall, Barcelona

1.2. Martorell, J. (1989) Tirant lo Blanc, Maria Aurèlia Capmany adapt; Manuel Boix ilustr; Edicions Proa, S.A, Barcelona.

1.3. Martorell, J. (1998) Tirant lo Blanc, Maria Aurèlia Capmany adapt; La Galera, S.A. Editorial, Colección: Polissons, Barcelona.

1.4. Martorell, J. (2005) Tirant lo Blanc contat als infants, Rosa Navarro Durán adapt; Empar Bruno Gómez y Pau Joan Hernàndez trad; Francesc Rovira ilustr; Marjal, Mislata.

1.5. Martorell, J. (2005) Tirant lo Blanc explicat als infants, Rosa Navarro Durán adapt; Pau Joan Hernàndez trad; Francesc Rovira ilustr; Edebé, Barcelona.

1.6. Martorell, J. (2006) Tirant lo Blanc, Mònica Abad adapt; Montse Ginesta ilustr; Susaeta, Barcelona.

1.7. Martorell, J. (2006) Galba, Martí Joan de Tirant lo Blanc, Josep Franco adapt; Enric Solbesn ilustr; Edicions Bromera, El Micalet Galàctic, Alzira.

1.8. Martorell, J. (2006) Tirant lo Blanch de Joanot Martorell, José Vicente Miralles Piles adapt; Enrique Climent Llopis ilustr; L'Oronella Servicis Editorials Valencians SL, El Butoni 1, València.

1.9. Martorell, J. (2008) Tirant lo Blanc, Ismael Torres adapt; Albert Hauf pról; Jesús Gabán ilustr; Vicens Vives, Colección Cucanya, València

1.10. Martorell, J. (2008) Tirant lo Blanc, Ismael Torres adapt; Albert Hauf pról; Jesús Gabán ilustr; Vicens Vives, Colección Cucanya-Aitana, València.

El marco que nos hemos impuesto reduce a siete las adaptaciones seleccionadas, porque las diferentes ediciones de Maria Aurèlia Capmany contienen la misma adaptación, del mismo modo que las dos estampaciones de Rosa Navarro y las de Ismael Torres presentan un único texto verbal que atiende a las variantes orientales u occidentales de la lengua catalana, variaciones muy interesantes para un

1 Roger Llovet 1997 (El Masnou, Eina d'Escola); Maria Aurèlia Capmany 1974 (Gorg), 1977 (Teatre Edebé), 1980 (Eliseu Climent), 1987 (Edicions 3i4, Teatre), 1990, (Edicions 3i4, El grill); Bernat Joan i Marí 1995, (La Galera, Taller de teatre)

2 Jordi Bulbena 1990; Jaume Fuster 1991 (El Temps), 1992, 1993 (Edicions 3i4).

SCRIPTA, Revista internacional de literatura i cultura medieval i moderna, núm. 7 / juny 2016 / pp. 102 - 128 ISSN: 2340-4841 · doi:10.7203/SCRIPTA.7.8444 
posible estudio sociolingüístico. La edición preparada por Mónica Abad para Susaeta dirigida a un público infantil, aunque empieza con el encuentro de Tirant con el ermitaño y acaba con la muerte del héroe y de su amada, no presenta las mismas ambiciones y, por tanto, no puede ser comparada con el resto de ediciones.

En el catálogo que a continuación presentamos, además de valorar la selección de secuencias de cada adaptación, hemos tenido en cuenta los elementos paratextuales que han concurrido en cada uno de los volúmenes, así como la adaptación al tramo lector al que supuestamente va dirigida la publicación. También hemos reseñado si la adaptación abre sus puertas a una lectura de la obra original o no. Las pautas seguidas para la exploración detallada de cada ejemplar están tomadas fundamentalmente de Lluch (2009).

1. Martorell, J. (1979) Tirant el Blanc. Adaptació per a nois i noies, Joan Sales adapt; Ferran Solde vila prol; Elvira Elías ilustr; Edicions del Mall, Barcelona.

Esta adaptación (Barcelona, 1954) se publicó con prólogo de Ferran Soldevila y dibujos de Elvira Elías en la Editorial Ariel, colección Rondalles donde cuajó un proyecto literario con clara voluntad pedagógica disfrazada de literatura infantil.

El libro consta de 240 páginas, $17 \times 25 \mathrm{~cm}$, la única referencia a la franja de edad de los destinatarios es per a noi $i$ noies. ${ }^{3}$ En la cubierta aparece el título de la obra, y los nombres del autor, adaptador y prologuista además de una ilustración que representa un caballero, lanza en ristre, en posición de ataque. Se trata de una copia del Retaule de Sant Jordi de Pere Niçard (1468, Museu Diocesà de Mallorca). El lomo indica título y autor; en la contracubierta y en la portadilla puede leerse el nombre de la colección. En la portada, vuelve a aparecer el título el nombre del prologuista, el de la ilustradora y el del autor de la adaptación y del vocabulario: Joan Sales, además, de una ilustración de Tirant empuñando la espada.

El prólogo de Ferran Soldevila, que se inicia con una loa a la labor de Sales, explica el valor de Tirant lo Blanc en la historia de la cultura catalana. A continuación el adaptador expone la elección del registro lingüístico.

En esta adaptación, se ha concedido enorme importancia a la ilustración, ocupa el 50\% del total de páginas. Las imágenes son secuenciales, congelan un punto del capítulo pero no aparecen en sincronizadas con el texto verbal verbal sino que anticipan o recuerdan algún hecho.

\footnotetext{
3 La primera edición de esta obra se publicó en Barcelona en 1954 en la colección Rondalles de l'Editorial Ariel, Barcelona. Esta misma edición, con diferentes cubiertas e ilustraciones en blanco y negro, ha sido reeditada en 1979 (Edicions del Mall-Grup Promotor Barcelona en la colección «Els llibres amb cua», con el subtítulo Adaptació per a nois i noies en la cubierta) y en 1990 (Columna Edicions en una edición conmemorativa de l'Any del Tirant, Barcelona). Y el texto verbal sin las ilustraciones de Elvira Elias y sin el vocabulario, ha sido reeditado en tres ocasiones: 1985 (Editorial Laia, colección «El Nus», Barcelona, con varias reimpresiones); 1990 (Columna Edicions, colección «Bumerang», Barcelona, con varias reimpresiones) y 1996 (Columna Edicions, colección «Columna Xip», Barcelona, con varias reimpresiones).
} 
Todas las ilustraciones ejecutadas en monocromía compensada con texturas reiterativas, están realizadas en un claroscuro contrastado, presentan un trabajo similar a la punta seca próximo al grabado. En cambio, los diseños se aproximan al lenguaje del cómic. Los drapeados, en ocasiones hiperbólicos, evitan el estudio anatómico de los personajes. Ornamentación propia de técnicas gráfico-plástica. Destacan las perspectivas cónicas, frontales y oblicuas. Se trata de imágenes cerradas que alternan formato grande y pequeño con una localización irregular en la página.

El estilo es heterogéneo tanto en la técnica como en la recreación de espacios y personajes. Las ilustraciones oscilan entre el realismo, la mayor parte de las veces, y los guiños a las representaciones ingenuas propias de un dibujo infantil —aparece una Luna con rostro humano (p.143). También se observa contraste entre los personajes masculinos, dibujados con trazos angulosos, y los femeninos diseñados con líneas más suaves y redondeadas y con excesiva prolongación de cuello y extremidades. Cuando recrea escenas orientales, se observa profusión de detalles tanto en la arquitectura como en los drapeados.

La presencia de la arquitectura es escasa en las ilustraciones y en todos los casos se trata de construcciones medievalizantes en unos casos realista y en otras idealizada tanto palacios musulmanes como castillos cristianos. La tumba de Tirant i Carmesina aparece enmarcada en una ojiva gótica. Los doseles de los tronos presentan arcos apuntados.

En las ilustraciones de esta obra, el día es el tiempo no marcado. En cambio, cuando la acción que se narra en el capítulo se desarrolla por la noche, el ilustrador representa a los personajes que asemejándose sombras chinescas.

Sales redujo la obra a una décima parte de sus páginas sin que se perdiese, en el resultado, el espíritu de la obra de Martorell. La división ha buscado estructuras narrativas nuevas en las que Sales ha modificado el orden de la narración del hipotexto verbal. Los capítulos presentan unas unidades bien trabadas que se adecuan a la morfología de los cuentos. La adaptación de Sales muestra cambios argumentales —el suicidio de la Viuda Reposada en Martorell queda resuelto por Sales en un hilarante dolor de barriga; llama al protagonista Tirant de Roca-Salada y Gegant Kirieleison a Kirieleison de Muntalbà, por ejemplo. Desparecen personajes de la obra de Martorell.

En múltiples ocasiones se observa la incursión del narrador en el flujo de la narración. Esto que ya sucedía en la obra de Martorell con un plural inclusivo para interpelar al personaje o al narratario, es llevado al extremo por Sales que introduce una primera persona del singular en alguna ocasión enfatizada pleonásticamente: que a mi si em daven tan regalada vida també em sortirien quatre roses $i$ sis clavells a cada galta i no faria la cara que faig. (p. 139).

Con el fin de no ralentizar el ritmo que se ha impuesto, Sales rehuye las descripciones con lo cual la ilustración cobra importancia a la hora de conocer personajes y espacio. A excepción de Carmesina que es descrita prolijamente (p.76), la descripción de los personajes, es somera, en ocasiones con un par de adjetivos calificativos - Felip agraciat però molt curt d'enteniment (p. 18); bella i discreta Ricomana (p.61). 
El cambio de género y de destinatario obliga a Sales no solo a meras modificacines ortográficas - adapta antropónimos y topónimos a la normativa fabriana - sino a un cambio de registro lingüístico aunque mantiene un léxico específico y una sintaxis medievalizante —uso deliberado del hipérbaton, formas pasivas de los verbos, ablativos absolutos, uso del adverbio com con valor temporal. No podemos perder de vista que que la colección Rondalles de Ariel, donde fue publicada por primera vez esta obra, pretendía una educación lingüística y estética de los catalanoparlantes.

Valoración. La idea de Sales a principios de los años cincuenta era ganar un público lector que se familiarizase con los grandes nombres y épocas de la historia de la literatura catalana y que, al mismo tiempo, favoreciese la unidad entre los catalanoparlantes. Aunque la adaptación fue destinada a un público infantil, se ofreció, como indica el prólogo, al gran público. La adaptación de Sales puede ser calificada de recreación tanto por los cambios argumentales que introduce como por la presencia del narrador en el relato. El registro lingǘ́stico elegido tanto por el léxico como por la sintaxis dista bastante del habitual en los jóvenes de principios del siglo XXI. La adaptación es ágil y el ritmo impuesto por Sales no decae. Es una edición que podría crear en el lector el grado de satisfacción suficiente que impidiese la lectura posterior de la obra en su versión original. Está adaptado al catalán oriental.

2. Martorell, J. (1989) Tirant lo Blanc, Maria Aurèlia Capmany adapt; Manuel Boix ilustr; Edicions Proa, S.A, Barcelona.

Esta edición apareció en el año anterior al dedicado a Tirant lo Blanc. En el año 1990, l'any del Tirant, se celebró el quinto centenario de la primera edición de la obra de Martorell y para festejarlo se organizaron diferentes eventos con la finalidad de dar a conocer la obra en todos los ámbitos, sobretodo en el escolar, para lo cual se prepararon ediciones adaptadas. Esta celebración recibió el apoyo de las administraciones autonómicas catalana, valenciana i balear así como de la práctica totalidad de las instituciones culturales.

Maria Aurèlia Capmany ${ }^{4}$ adaptó para Proa una edición que consta de 92 páginas, con un formato de 25x19 cm, en cartoné. En la primera edición, no se advierte sobre la franja de edad del lector, en cambio en la nota preliminar a la segunda edición (1990) dice que se trata de una adaptació per a infants aunque el tipo de edición supone un nivel lingüístico y de formación estética algo superior al público juvenil actual.

Esta edición presenta ilustraciones muy detallistas a tinta china y acuarela a cargo de Manuel Boix. La cubierta dividida en tres partes muestra en el segmento central el título de la obra y los nombres del autor, adaptadora e ilustrador; en la parte inferior, se observa una estatua ecuestre de Tirant sobre un pedestal encuadrado en una estructura clásica de columnas que sustentan una bóveda

4 Maria Aurèlia Campmany realizó varias adaptaciones de Tirant lo Blanc: Edicions Proa colección El Fanal de Proa (1989); La galera editorial (1998); adaptaciones teatrales Edicions Don Bosco, (1977) Teatre Edebé; Tres i Quatre (1987); Gorg (1974); Eliseu Climent (1980); Tres i Quatre, colección El grill (1990); La Galera colección Polissons(1998).

SCRIPTA, Revista internacional de literatura i cultura medieval i moderna, núm. 7 / juny 2016 / pp. 102 - 128 ISSN: 2340-4841 ·doi:10.7203/SCRIPTA.7.8444 
de cañón sembrada de estrellas. Los tres medallones de la zona superior muestran un retrato de Carmesina flanqueada por los anagramas de Tirant y de su amada, uno en cada medallón lateral, consumidos por llamas de fuego. ${ }^{5}$ La contracubierta presenta un escueto resumen de la obra y una brevísima explicación de los objetivos de la colección, el perfil profesional de los editores y el público a quien se dirige.

La adaptación se divide en cinco capítulos que coinciden con las partes principales de la novela de Joanot Martorell. El ejemplar alterna dos páginas escritas a línea tirada con ilustraciones a doble página que alivian la densidad de un texto verbal en el que capítulo y párrafo son equivalentes. Además de las grandes estampas, aparecen otras de tamaño menor que, ocupando el tercio central del segundo cuarto superior de cada página, dificultan la lectura porque la línea queda interrumpida.

Encontramos un total sincronización entre el texto verbal y las ilustraciones, se puede seguir el hilo de la narración a partir de las ilustraciones. Cada capítulo comienza con una ilustración que ocupa la mitad superior de la caja de escritura. Las imágenes se han congelado siguiendo las proposiciones elegidas para el desarrollo de la adaptación, a través de ellas podemos seguir el hilo de la narración. Los personajes ilustrados por Boix presentan un cierto hieratismo que confiere una solemnidad adecuada a la tragedia final de la obra. En las imágenes de grupo, los primeros planos están muy trabajados, en cambio la composición de las figuras de relleno se reducen a manchas de tinta y perfiles simplemente indicados.

En las ilustraciones de Boix, el espacio es simbólico y totalmente parangonable con la iconografía medieval. Los espacios interiores, en su mayoría, aparecen pintados de azul, mientras que se reserva el amarillo para los exteriores. El dibujo es simbólico.

El texto verbal está dividido en cinco capítulos coincidentes con las partes principales de la novela de Joanot Martorell: Tirant en Inglaterra, en Sicilia y Rodas, en el imperio griego, en el Norte de África y, finalmente, la liberación del Imperio Griego y muerte de Tirant. Ahora bien, la selección llevada a cabo no es equitativa, si no que se han eliminado aquellos episodios que pudiesen ralentizar el ritmo requerido por un público ávido de aventuras. Como se observará en la tabla, Capmany reduce a un tercio las proposiciones en las se ha resumido Tirant lo Blanc.

El narrador extradiegético mantiene distancia respecto a la trama, toda la instrucción viene de la voz de los personajes. Capmany buscó un ritmo acelerado para su adaptación, por ese motivo las secuencias descriptivas son mínimas, La caracterización espacio-temporal no resulta relevante. Las ilustraciones de Boix complementan la descripción de los personajes que queda reducida a simples

5 La explicación de la portada la encontramos en la página 86: La tomba estava dins una capella de volta, els arcs de la qual eren de pòrfir i recolzaven sobre quatre pilars de jaspi. La clau del creuer era d'or massís buidada, guarnida amb moltes pedres fines. (...) Del punt més alt de l'església penjaven moltes banderes i penons i estendards de diverses ciutats i provincies guanyades victoriosament. Mes entre totes es deplegaven les divises de Tirant: flames o llengües d'or sobre carmesí i flames de foc sobre fons d'or. En les flames d'or es cremaven les lletres: C.C.C. $i$ en les flames de foc es cremaven aquestes: T.T.T. Significava que l'or del seu amor cremant, s'apurava en les flames de Carmesina i que la Princesa ardentment s'apurava en les flames del seu voler.

SCRIPTA, Revista internacional de literatura i cultura medieval i moderna, núm. 7 / juny 2016 / pp. 102 - 128 
adjetivos: virtuós Rei d'Anglaterra (p. 11) o Felipe de Francia flac d'esperit (p.31). De Tirant, personaje principal, solamente sabemos el veredicto del heraldo: Donem fe que aquest gentilhome no és coix ni esguerrat de cap dels seus membres i està dipost per entrar en batalla i és digne mereixedor de l'orde de cavalleria (p. 18); Bella Agnès, per vostra molta bellesa i les altres virtuts...(p.22) gegantàs Kirieleison. (p.30)

El léxico, muy cuidado, no se adecua al registro infantil, como dice la nota preliminar a la segunda edición, sino más bien, y con algunos reparos, al juvenil. En reiteradas ocasiones, la búsqueda de un registro arcaizante, con un vocabulario específico ineludible aumenta la dificultad de la comprensión por un público juvenil.

Valoración. La selección de la información es adecuada y, obviamente, no se respeta la lengua del autor. La disposición tipográfica no facilita la lectura del texto verbal. Exige un nivel lingüístico y de formación estética algo superior a nuestro público juvenil. Es una edición que podría crear en el lector el grado de satisfacción suficiente que impidiese la lectura posterior de la obra en su versión original. Está adaptado al catalán oriental.

3. Martorell, J. (2006) Tirant lo Blanc, Mònica Abad adapt; Montse Ginesta ilustr; Susaeta, Barcelona.

Durante el año 2004, año dedicado al Quijote, se publicaron múltiples adaptaciones de la novela de Cervantes procurando ajustarse a las diversas necesidades de los lectores. El éxito editorial sugirió que se podría aplicar el mismo esquema a Tirant lo Blanc: una adaptación para cada edad. La edición que analizamos apareció en 2006 y no presenta mención alguna del público a quien va dirigido.

En un primer examen, podríamos concluir erróneamente que está pensada para neolectores, puesto que las ilustraciones parecen ser preparadas para niños que empiezan a distinguir entre el mundo y su representación, pero el nivel de autonomía lectora exigido por el texto verbal contradice a los paratextos.

Las medidas del libro, 22x22 cm, encajan en los parámetros del formato del libro infantil. En la ilustración de la cubierta, se observa a Tirant que, guarnecido con una armadura, contempla desde las costas de Bretaña el barco que lo conducirá a Sicilia. La escena está enmarcada por unas cortinas a modo de telón de teatro. Sobre este fondo, en la parte superior central, aparece el título y en la inferior la editorial. La portada, que mantiene el mismo diseño que la cubierta, añade el nombre de la adaptadora y de la ilustradora. En la página anterior aparecen los créditos: editorial, adaptadora e ilustradora.

Las ilustraciones son esquemáticas y realizadas a tinta plana con colores básicos, la línea es muy expresiva y los espacios quedan definidos por una línea que marca el horizonte. La maquetación alterna rítmicamente las páginas al texto verbal, las pares, con las ilustraciones siempre situadas en las impares. En ocasiones, los dibujos no son descriptivos sino simbólicos, lo cual dificulta la 
comprensión del texto verbal por parte de un público infantil. Además, la ilustración congela el elemento primordial del texto verbal, pero en su gran mayoría no observan un criterio cronológico que nos ayude a entender la historia.

En este libro parecen entrar en contradicción las ilustraciones imágenes estáticas de rostros caricaturescos con una representación del mundo sencilla, con el texto verbal parece dirigido a un público infantil ya avezado a la lectura.

Además encontramos iconografía medieval — pavo real (p.24), un perro junto a la princesa Carmesina (p.22) o un surtidor de agua - que pueden ser un guiño, totalmente desubicado, a la erudición.

La ilustración correspondiente al caballero-ermitaño muestra un hombre de barba rala vestido con hábito franciscano, en cambio la descripción del original lo presenta ab los cabells larchs fins a les spatles e la barba fins a la cinta, tota blanca, (Hauf, 2008:86) Esto defrauda al niño.

Esta adaptación parece atender más a los personajes que a la narración del original. Allí aparecen: Guillem de Varòic, Felipe de Francia, la princesa Ricomana, la princesa Carmesina, la Viuda Reposada. Dedica el último capítulo a la muerte del héroe y la princesa.

Las diversas partes de la novela original no aparecen compensadas porque dedica dos páginas a Guillem de Varòic (pp. 8 y 10); tres páginas a Felipe de Francia (pp.12, 14 y 16).

Esta adaptación, como todas, trata de presentar un ritmo acelerado para lo cual usa siempre que es posible el estilo directo, reduce toda la narración a anécdotas por lo tanto, la presencia del narrador es mínima. También aquí podemos encontrar la causa de las escasas descripciones, solamente encontramos dos personajes descritos: Felip era un noi no gaire intel ligent, més aviat tanoca; no gaire ben plantat, més aviat leig; i no gaire estimat, més aviat menyspreat. (p.12); Tirant es descrito como coratjós cavaller (p.22)

El registro lingüístico exige un lector autónomo que podríamos situar en el segundo ciclo de educación primaria. Está escrito en variedad oriental: Noi (p.8); tornis (p.8);

Valoración. Por la preponderancia del dibujo sobre el texto verbal y las características del formato, queda claro el propósito de dirigirse a neolectores. Nos parece una selección adecuada de las aventuras y desventuras de Tirant. Evidentemente no se respeta la lengua de Martorell, ya que deliberadamente se reescribe un texto verbal con todas las características de una narración infantil. Esta adaptación facilita al niño los referentes culturales que le puedan llevar a la lectura de la obra de Martorell en versión original. Las variantes morfológicas del libro son catalanoorientales. 
4. Martorell, J. (2005) Tirant lo Blanc contat als infants Rosa Navarro Durán adapt; Empar Bruno Gómez y Pau Joan Hernàndez trad; Francesc Rovira ilustr; Marjal, Mislata; Martorell, J. (2005) Tirant lo Blanc explicat als infants, Rosa Navarro Durán adapt; Pau Joan Hernàndez trad; Francesc Rovira ilustr; Edebé, Barcelona.

Esta adaptación llevada a cabo por la prestigiosa medievalista catalana Rosa Navarro Durán contó para su promoción con un importante apoyo propagandístico. De hecho la obra se presentó en noviembre de 2005 en diversos lugares con alguna nota de prensa.

La adaptadora señaló que pretendía conseguir con esta adaptación que tant els més menuts com els adults, «perden la por» de acercarse a un clásico.

La versión se publicó en castellano y en catalán oriental y en valenciano: Tirante el Blanco contado a los niños, Tirant lo Blanc contat als infants y Tirant lo Blanc explicat als infants. La noticia generada por la Academia Valenciana de la Lengua obvió este último detalle.

La nota de prensa entrecomilló palabras de Navarro Durán a més de la sena gran bellesa literària, el clásico de las letras valencianas és transmissor d'importants valors socials, por ejemplo: important presència que la dona té en el relat $\mathrm{O}$ al hecho de que las batallas no sols es guanyen per la força, sinó també gràcies a la intel vigència.

Este Tirant para niños forma parte de una nueva colección iniciada por Edebé con el fin de acercar los principales clásicos de la literatura a los lectores más jóvenes. No se menciona explícitamente la edad de los receeptores de la adaptación, pero la densidad del texto verbal en su conjunto reclama un lector autónomo y predispuesto a una lectura larga.

Tanto el formato - 200 páginas de 24x20, en cartoné- como el ritmo entre texto verbal e ilustración son suficientemente atractivos para el público infantil a quien se dirige la publicación. La cubierta y contracubierta presentan, en una única ilustración, el momento en el que Tirant y sus secuaces ponen el pie en Rodas recién liberada, al fondo se pueden observar, en llamas, las naves genovesas amarradas unas junto a otras. Esta misma ilustración se repite en la protección de la cubierta en cuyas solapas se indica la valoración cervantina del Tirant, así como las fechas de nacimiento de Joanot Martorell, del inicio de la escritura y las de las primeras publicaciones de Tirant lo Blanc en catalán y en castellano.

En el centro del tercio superior de la cubierta, aparece el título de la obra y los nombres de la adaptadora y del ilustrador. En la contracubierta se indica Versió per a infants de la novel ta Tirant lo Blanc de Joanot Martorell además del logo de la colección. En los créditos podemos leer la editorial, y los nombres de la adaptadora, el ilustrador, la traducción, del director editorial y del diseñador. La portadilla indica el nombre de la obra, la editorial y la colección. A continuación aparece el índice.

El ritmo de los capítulos es constante: una media de 3 a 4 páginas, siempre con las ilustraciones oportunas. Los dibujos de Rovira están presentes en todos los capítulos del libro 
con un exhaustivo trabajo de acomodación al texto verbal y al receptor infantil tanto por el color, siempre apastelado, como por la aparición de líneas cinéticas que lo aproximan al lenguaje del cómic con un registro desenfadado que no hace justicia al personaje dramático que es Tirant.. El tratamiento de las figuras es contrastado con unos fondos uniformes. Presentan trabajo de línea con claroscuro. Todos los rostros lucen los mismos ojos e idéntica nariz porque el ilustrador se centra en la acción de ritmo acelerado que no decae en ningún momento. Las ilustraciones son semejantes a fotogramas. Congela la imagen en los picos resolutivos. Al principio de cada capítulo aparece un icono que coincide con el objeto más significativo del capítulo.

En los interiores se producen abundantes elipsis espaciales. También encontramos elementos iconográficos - por ejemplo la aparición de las mariposas en las ilustraciones en las que Carmesina se muestra como enamorada.

Rosa Navarro presenta su adaptación dividida en treinta y dos capítulos que siguen, sin hacer mención explícita, las cinco partes de la novela de Martorell. Cada capítulo está indicado con letras mayúsculas y siempre aparece un elemento iconográfico que lo identifica con la acción que cuenta.

La ausencia de descripciones — quedan reducidas a simples adjetivos - confiere a la adaptación un ritmo más bien rápido en el que la voz del narrador adquiere una gran importancia puesto que el estilo directo es poco utilizado.

Tenemos un ejemplar publicado por Marjal en Mislata (Valencia) que observa todas la variantes morfológicas, y alguna sintáctica, valencianas. En lo que al léxico se refiere, descuida algunas palabras patrimoniales valencianas por variables más neutras —atxa (p. 30) por destral. En cambio, el ejemplar publicado por Edebé en Barcelona es más permisivo en la observancia de las variantes morfológicas orientales: en reiteradas ocasiones presenta plurales procedentes de antiguos proparoxítonos formados por -ns (p. 90) más propios del catalán occidental. Tampoco parece tener inconveniente en introducir variantes léxicas occidentales por ejemplo colps (pp. 19 y 119). Todas estas circunstancias nos inducen a pensar que la adaptación castellana podría haber sido la original y desde ella se habrían traducido los dos texto verbals catalanes.

Valoración. Se trata de una buena adaptación de los pasajes seleccionados. Incita a una posterior lectura de la obra original. Aunque el libro esté aligerado por las ilustraciones, parece estar dirigido a lectores de 10 a 12 años con alto hábito de lectura. Las ilustraciones de Rovira son abundantes y adecuadas para un público infantil. La extensión del libro queda atenuada por la estudiada división en capítulos.

5. Martorell, J. (2006) Galba, Martí Joan de Tirant lo Blanc, Josep Franco adapt; Enric Solbesn ilustr; Edicions Bromera, El Micalet Galàctic, Alzira.

Franco preparó para Edicions Bromera una adaptación del Tirant en 64 páginas de 21x23 cm. El formato quiere indicar que se dirige a un público juvenil. 
El tercio superior de la cubierta indica el título del libro, los nombres del autor, adaptador y dibujante, también el nombre de la colección. Los dos tercios de inferiores de la portada muestran en la imagen ecuestre de un caballero espada en mano. El lomo de esta edición indica el título de la obra, el autor, la editorial y el número que corresponde el presente libro en la colección. En el tercio superior de la contracubierta, aparece indicado que esta adaptación forma parte de la sección sèrie blava, colección El Micalet Galàctic, especialmente indicada para mayores de 12 años. La mitad del tercio central de la contracubierta está dividida en dos columnas, la primera ilustrada con un barco, en la segunda columna aparece un resumen de las claves temáticas del Tirant y la importancia de esta novela en la literatura valenciana. A continuación se puede leer la valoración literaria del adaptador. En el extremo derecho del tercio inferior aparece el logo de Edicions Bromera.

En el centro de la portadilla aparece el logo de la editorial, en el tercio inferior de la siguiente página podemos leer los créditos del libro. Los dos tercios superiores indican los últimos libros que forman la colección, así como el director. El diseño de la portada es idéntico al de la cubierta. A continuación, a modo de prólogo se ha copiado un párrafo de la dedicatoria de Tirant lo Blanc al Sereníssimo príncep don Ferrando de Portugal. Las dos últimas páginas del libro están ocupadas por el índice y un glosario, donde se explica el léxico insoslayable en una adaptación de este género.

Las ilustraciones ocupan un cuarto del total de páginas del libro, porcentaje totalmente adecuado para adolescentes a quienes presentan algunos señuelos de claro criterio comercial.

El ilustrador ha optado por el arcaísmo, para lo cual ha eliminado la perspectiva euclidiana — se observan múltiples perspectivas en un solo dibujo- y ha presentado unos personajes rígidos. La mayor parte de las escenas no presentan acción, sino que ésta viene sugerida por los elementos iconográficos que pudieran estar involucrados en ella. Se advierte un cierto horror vacui. Las ilustraciones congelan los momentos álgidos de cada capítulo, de tal manera que, a partir de ellas, podemos seguir, de modo resumido, toda la narración.

No aparecen descripciones de los personajes, sino que tenemos que espigar adjetivos sueltos a lo largo de la narración, por tanto las ilustraciones nos muestran el físico de los personajes. La mayor parte de las ilustraciones presenta escenarios exteriores con abigarradas ciudades o mares embravecidos. Los escenarios interiores, siguiendo la ya nombrada intención arcaizante, exhiben suelos ajedrezados y ventanas góticas. Algunas resoluciones son un tanto naif - por ejemplo el fondo marino que muestra al marinero cruzando una cuerda por la argolla del barco al que desea prender fuego. Las ilustraciones no mantienen relación entre sí. El registro es realista con rostros inexpresivos frente a cualquier situación.

La narración se divide en cinco grandes partes igual que el original. Los capítulos de la adaptación no siguen una estructura interna sino que son una simple adición de múltiples secuencias narrativas expuestas acumulativamente siguiendo el orden del original. Esta acumulación buscada intencionadamente, confiere a la narración un ritmo rápido del que quedan excluidas las secuencias 
descriptivas que ralentizarían la agilidad de la narración. Las descripciones de los personajes no atienden a la importancia de estos en el conjunto de la novela, sino que se presentan personajes importantes a quienes se les adscribe un solo adjetivo por ejemplo Plaerdemavida — donzella molt amiga de la princesa (p. 44) — o la Viuda Reposada - malvada (p. 47). Solamente encontramos dos personajes a quienes se les dedica una secuencia descriptiva: el ermitaño y Carmesina - s'admirà dels seus cabells d'or, de les celles que pareixien fetes amb pinzell, dels ulls, semblants a dues estreles redones, del nas prim $i$ afilat, dels llavis rojos com el corall $i$ de les dents blanquíssimes. (p.38). Del personaje principal solo describe un vestido - en este caso la ilustración no es tan prolija como el texto verbal.

Observamos un buen ajuste entre el nivel de la adaptación y la competencia lingüístico-literaria de un escolar de 12-14 años.

Valoración. La selección de los pasajes es adecuada. Las ilustraciones presentan múltiples señuelos a muchachos adolescentes ¿criterio comercial? En su deseo por adaptar la lengua de Martorell a la lengua estándar ha generado algunos errores de adaptación lingüística. Facilita la lectura posterior del original.

6. Martorell, J. (2006) Tirant lo Blanch de Joanot Martorell, José Vicente Miralles Piles adapt; Enrique Climent Llopis ilustr; L’Oronella Servicis Editorials Valencians SL, El Butoni 1, València.

Esta adaptación, escrita con las Normas Ortográficas de El Puig, va precedida por una presentación a cargo del coordinador de la colección cuyo objetivo parece ser la publicación de llibres iniciatics $i$ volem fer dansar al ritme d'El Butoni als nostres héroes lliteraris. En llengua valenciana, clar. Es un libro Per a chiquets i majors.

Entre los paratexto verbals aparece una copia de la dedicatoria de Martorell al Serenissimo príncep don Ferrando de Portugal donde menciona que ha traducido la obra en lengua vulgar valenciana. A continuación, una biografía de Martorell seguida del índice del libro. El mediador trata de instruir sobre: el placer de leer, la competencia establecida entre el audiovisual y la lectura y los rasgos identitarios valencianos.

Define esta adaptación como diferente al resto: No s'ba centrat en una part de l'història considerada més atractiva, com han fet unes atres adaptacions. Ans al contrari: esta versiópermet tindre un primer coneiximent global de la novela de Martorell en tots el seus aspectes: bèlic, amorós, cortesà i religiós.

En la cubierta aparece el título de la obra junto con los nombres del autor, adaptador e ilustrador. La ilustración de la cubierta presenta un caballero con armadura cabalgando, con la bandera valenciana, sobre una espada engalanada con una guirnalda de flores. En la parte inferior se observa el logo de la colección: El butoni. 
El lomo presenta el título, el nombre del autor, el número del volumen en la colección, 1, y el logo de la editorial l'Oronella. La contracubierta está compuesta por una ilustración el tercio superior izquierdo; la franja inferior muestra los logos de la Associació d'escriptors en llengua valenciana, la Real Academia de Cultura Valenciana, Lo Rat Penat y la editorial la Oronella.

La portadilla consta de una ilustración que representa dos caballeros sobre la proa de un barco con una divisa que trata de sintetizar la ambición de Tirant: el honor de la caballería. La portada muestra título y autor con los nombres de adaptador, ilustrador y coordinador de la ilustración en la parte central inferior se observa el logo de la colección el Butoni. La página dedicada a los créditos indica, además, una definición de butoni y los curricula vitae del adaptador y del ilustrador.

Las ilustraciones de Enrique Climent no son uniformes: en unas destaca la línea, con reminiscencias al grabado, mientras que en otras hay un claro predominio del color, con tonos cálidos poco contrastados. El estudio anatómico, con algún desnudo grotesco casi pornográfico, simplemente esbozado y un tratamiento barroco de los drapeados.

El aspecto de la maquetación no es homogéneo. Presenta algunas deficiencias tanto por la dirección de las ilustraciones, — se observa un mapa orientado en sentido inverso a la lectura, (p. 76) — como por la relación reticular del mensaje icónico y del verbal. En algún caso la ilustración se corta a sangre en los márgenes superior e inferior, en tanto que los márgenes derecho e izquierdo tienen diferente grosor (p. 35). En otras ocasiones, con idéntico diseño, la páginas aparece enmarcada (p. 103). Las ilustraciones muestran márgenes en blanco a los lados. En las páginas 48 y 56 la ilustración cortada a sangre en tres márgenes, mientras el cuarto invade la página siguiente. El colofón está mutilado: faltan todas las vocales con acento gráfico. El espacio, mucho atrezo en interiores, presenta elementos circunstanciales sin papel en el texto verbal: una rana (p. 14) un lagarto (p. 78)

Aunque no es una adaptación teatral propiamente dicha, por la inclusión continuada del estilo directo, podría ser apto para su dramatización, lo cual limita la presencia del narrador. Éste simplemente aparece cuando se da un salto en el tiempo, o bien para dar una explicación que centre el pasaje. En algunos casos la voz del narrador pasa a alguno de los personajes. La presencia del narrador queda marcada por la sangría.

Las descripciones de los personajes son mínimas: Felip — grosser i tarambana (p. 29), Ricomana — de gran bellesa (p. 32), Carmesina —extraordinària bellea (p. 44), Viuda Reposada — mal caràcter (p.44).

La presencia de continuas llamadas a pie de página para explicar el vocabulario incomoda la lectura por innecesaria —contentació=alegría (p.17); Irlanda = Nació que en aquell temps ocupava tota lilla bui dividida en Irlanda i Irlanda del Nort (p.17) — y, en algunas ocasiones, la entorpece porque el sinónimo elegido es de mayor complejidad explicativa. 
Introduce vocabulario que interpreta el registro de la novela de Martorell aproximándolo a las acotaciones sainetescas: ¿I per tant poca cosa arriscaríeu la vida? — contestà, caragolera, Agnés.

Valoración. La adaptación presenta una selección de la información descompensada. Obviamente no se respeta la lengua del autor. Es una edición preparada per a chiquets o majors cuya lectura no facilita el acceso a la versión original.

7. Martorell, J. (2008) Tirant lo Blanc Ismael Torres, adapt; Albert Hauf, prol; Jesús Gabán ilustr; Vicens Vives, Cucanya/ Cucanya-Aitana, Barcelona.

Torres presenta una edición prologada y supervisada por Albert Hauf, uno de los máximos especialistas de Tirant lo Blanc. Aunque no se indica la franja de edad a quien se dirige la edición, las notas a pie de página, el prólogo, la guía didáctica y el ritmo de las ilustraciones sugieren un público juvenil relacionado con un ambiente académico. En la página web de la editorial además de indicar las características de la edición indica los valores que esta adaptación puede fomentar en sus lectores: amistad, compañerismo confianza, criterio propio, generosidad, honradez, imaginación justicia, responsabilidad y valentía.

La editorial Vicens Vives, siguiendo a criterios comerciales, ha publicado dos versiones del mismo libro atendiendo a la realidad sociolingüística valenciana. Aitana es el nombre de la colección valenciana de Cucanya. La colección Cucanya atiende a la variedad de catalán oriental, mientras que Cucanya-Aitana observa las variantes valencianas

Esta edición de 211 páginas, 22x16, pensada con unos fines didácticos, cuenta con una guía de lectura que pone de relieve aquellos elementos más significativos de cada capítulo. El diseño de la cubierta, tal vez por exigencias del estilo de la colección, no hace justicia al excelente trabajo de ilustración y maquetación presentado por el libro. El tercio superior de la cubierta indica, sobre un fondo blanco, el título y los nombres del autor, adaptador, ilustrador y prologuista. Sobre una franja superpuesta se puede leer en vertical el nombre de la colección: Cucanya. Los dos tercios inferiores están ocupados por la ilustración de un torneo: un caballero, lanza en ristre, sobre un fondo que muestra unas gradas con público y una recreación romántica de una ciudad medieval.

El lomo indica título y autor, el logo de la editorial y el número de la colección. La contracubierta, además de resumir la obra y mencionar al adaptador, prologuista e ilustrador, muestra el logo de la editorial Vicens Vives. Al margen izquierdo una franja vertical con el indicativo de la colección y un recorte de la ilustración del caballero de la cubierta.

En la portadilla, se observa el título de la obra con una pequeña ilustración de las bodas del rey de Inglaterra. En el reverso aparece el nombre del director de la colección. La portada indica el autor, el título, el nombre del revisor y prologuista de la edición, el adaptador, el ilustrador y el autor de la guía didáctica. Además del logo de la editorial, aparece una ilustración en la que observamos a Tirant en espera de ser armado caballero. En el reverso, se pueden leer los créditos de la edición. A 
continuación aparece el índice con la indicación del prólogo, capítulos, y dos anexos: un mapa y las actividades que guían la lectura.

Albert Hauf relaciona las circunstancias históricas vividas por Martorell con la ficción literaria creada por el autor valenciano en su novela donde coinciden los triunfos militares con los amorosos. Las características de la edición vienen indicadas en el prólogo: una versión sintética pero completa y bien articulada, que permita conocer y saborear lo más esencial del argumento y las características más distintivas del estilo para preparar una posterior lectura. (p.15)

Los diecisiete capítulos en los que se divide la adaptación muestran una selección de la información muy equilibrada atendiendo a todas las partes en las que se divide Tirant to Blanc.

El alto respeto por el original, la presencia de notas a pie de página, el prólogo y la guía de lectura conducen al crecimiento de la competencia lectora de quienes se acerquen a esta edición.

Las ilustraciones presentan buena disposición de los elementos, el dibujo es detallista y la coloración, realizada con acuarela, presenta tonalidades cálidas. Las láminas son de clara inspiración romántica. Las imágenes presentan tres tipos de maquetación: doble página, una página y media página.

Para las panorámicas de las ciudades, de puertos o de batallas reserva la doble página; la página entera se dedica a presentar a los personajes. Las ilustraciones que ocupan media página siven para mantener la secuenciación con las de gran formato y permiten seguir la historia a través de ellas. La ilustración es siempre estilizada y elegante, respeta el dramatismo de la obra de Martorell, siempre teniendo en cuenta el público a quien se dirige. Las imágenes coinciden totalmente con el texto verbal verbal, no reinterpretan sino que se ciñen a la información suministrada por el texto verbal.

Las secuencias descriptivas de esta adaptación son más numerosas que en las anteriores. El aumento de la descripción produce que disminuya la necesidad de las ilustraciones. Los personajes son descritos con mayor prolijidad que en las otras adaptaciones: Tirant,- Un jove noble $i$ somiador (...) tenia vint anys, (...) li sobrava valor (p.19) Daifebus_ cosí de Tirant (p.20)—, Guillem de Varòic —un vell esprimatxat de llargues barbes blanques, que duia un bäbit estripat de color terròs (p.20)-, la filla del rei de França — els seus cabells, que pareixien fils d'or fi, arribaven fins al terra i la blancor de les seues faccions $i$ de les seues mans resplendia com la neu. (p.27) — el rei d'Anglaterra; Felip — passava per ser ignorant i groller. (p.63)—; Ricomana —una donzella d'una bellesa increïble. (p. 64).

La mayor parte de las acciones ilustradas se desarrollan durante el día, excepto dos maniobras bélicas que suceden durante la noche. Ha reservado el alba para mostrar el encuentro amoroso entre Tirant y Carmesina. La ilustración plasma rigurosamente la información aportada por el texto verbal.

La adaptación de Torres, publicado en dos versiones atendiendo a pequeñas diferencias morfológicas y léxicas, ha seguido las cinco partes en las que se divide la novela original, aunque la división en capítulos elegida por el adaptador no las mencione. La estructura de cada capítulo finaliza con una conclusión abierta que sirve de introducción al capítulo posterior. 
La adaptación es muy equilibrada en lo que respecta a la selección de la información. El nivel de lengua, adaptado al léxico y normativa de la AVL, es exigente, y añade las aclaraciones necesarias sin interferir en el texto. Las ilustraciones, sin pretensiones arcaizantes, no desdicen de una obra medieval. Aunque la selección de los pasajes de la novela es equilibrada, la adaptación no cierra las puertas a una lectura posterior de la versión original.

\section{Secuencias de Tirant lo Blanch seleccionadas por las adaptaciones LIJ}

Aunque todas las adaptaciones que se han catalogado parten del mismo hipotexto y tratan de sintetizar la obra entera, cada una de ellas ha sido realizada con sus propios criterios y ha seleccionado las secuencias de la obra de Martorell que ha considerado importantes para su finalidad. Para comprobar la selección de pasajes, Tirant lo Blanc ha sido reducido a preposiciones sencillas, aun sabiendo que cualquier reducción es subjetiva. Se ha otorgado a cada adaptación una sigla $\mathbf{S}$ (Sales, 1979) C (Capmany, 1989); N (Navarro, 2005); A (Abad, 2006); F (Franco, 1990); O (Miralles 2006); T (Torres, 2008). Una X indica la aparición del tema en la columna de la sigla asignada a cada adaptación.

\begin{tabular}{|c|c|c|c|c|c|c|c|}
\hline Tirant en Inglaterra (capítulos 1 al 97) & $\mathbf{S}$ & $\mathrm{C}$ & $\mathbf{N}$ & $\mathbf{A}$ & $\mathbf{F}$ & $\mathbf{O}$ & $\mathbf{T}$ \\
\hline 1. Guillem de Varoic abandona a su esposa e hijo & & $\mathbf{X}$ & & & & & \\
\hline 2. Guillem de Varoic difunde el rumor de su muerte & & $\mathbf{X}$ & & & & & \\
\hline 3. Guillem de Varoic se convierte en ermitaño & & $\mathbf{X}$ & & & & & \\
\hline 4. El ermitaño vence al rey moro invasor & & & & & & & $\mathbf{X}$ \\
\hline 5. El rey de Inglaterra anuncia sus bodas & $\mathbf{X}$ & $\mathbf{X}$ & $\mathbf{X}$ & $\mathbf{X}$ & & & $\mathbf{X}$ \\
\hline $\begin{array}{l}\text { 6. La palidez de la princesa permite ver pasar el vino por } \\
\text { su garganta }\end{array}$ & $\mathbf{x}$ & & $\mathbf{X}$ & & $\mathbf{X}$ & & $\mathbf{X}$ \\
\hline 7. Tirant lo Blanc conoce al ermitaño & $\mathbf{X}$ & $\mathbf{X}$ & & $\mathbf{X}$ & $\mathbf{X}$ & & $\mathbf{X}$ \\
\hline 8. El ermitaño le explica el Orden de Caballería & & $\mathbf{X}$ & & $\mathbf{X}$ & & $\mathbf{X}$ & $\mathbf{X}$ \\
\hline $\begin{array}{l}\text { 9. Tirant, armado caballero, sale vencedor de numerosos } \\
\text { combates }\end{array}$ & $\mathbf{X}$ & $\mathbf{X}$ & & $\mathbf{X}$ & $\mathbf{X}$ & $\mathbf{X}$ & $\mathbf{X}$ \\
\hline 10. Tirant es examinado por un grupo de doncellas & $\mathbf{X}$ & & & & & & \\
\hline 11. Tirant se convierte en el mejor caballero & & $\mathbf{X}$ & $\mathbf{X}$ & & & & $\mathbf{X}$ \\
\hline 12. En tres combates a caballo mata a sus adversarios & & & & & & $\mathbf{X}$ & $\mathbf{X}$ \\
\hline 13. La bella Agnès da en prenda su broche & $\mathbf{X}$ & $\mathbf{X}$ & $\mathbf{X}$ & & $\mathbf{X}$ & $\mathbf{X}$ & $\mathbf{X}$ \\
\hline 14. Combate con el señor de las Vilesermes & $\mathbf{X}$ & $\mathbf{X}$ & & & $\mathbf{X}$ & $\mathbf{X}$ & $\mathbf{X}$ \\
\hline
\end{tabular}




\begin{tabular}{|l|c|c|c|c|c|c|c|}
\hline 15. Combate con el alano & $\mathbf{X}$ & $\mathbf{X}$ & $\mathbf{X}$ & & & & $\mathbf{X}$ \\
\hline 16. Tirant combate con los reyes & & $\mathbf{X}$ & $\mathbf{X}$ & & & $\mathbf{X}$ & $\mathbf{X}$ \\
\hline 17. La doncella Flor-de-Caballería y el león & $\mathbf{X}$ & & & & & & \\
\hline 18. Tirant retado por Kirieleison de Muntalbà & $\mathbf{X}$ & $\mathbf{X}$ & $\mathbf{X}$ & & & & $\mathbf{X}$ \\
\hline 19. Los bretones se despiden del ermitaño & $\mathbf{X}$ & & & & & & $\mathbf{X}$ \\
\hline
\end{tabular}

Tirant en Sicilia y Rodas (capítulos 98 a 114)

\begin{tabular}{|l|l|l|l|l|l|l|l|}
\hline 20. Tirant y los suyos son recibidos por el duque Bretaña & & & & & & & \\
\hline 21. El sultán de El Cairo sitia la isla de Rodas & & & $\mathbf{X}$ & & $\mathbf{X}$ & $\mathbf{X}$ & $\mathbf{X}$ \\
\hline 22. Solamente Tirant decide ayudar a los sitiados & & & $\mathbf{X}$ & $\mathbf{X}$ & & & $\mathbf{X}$ \\
\hline 23. Felipe, hijo del rey de Francia, se adhiere a la causa & & $\mathbf{X}$ & $\mathbf{X}$ & $\mathbf{X}$ & $\mathbf{X}$ & $\mathbf{X}$ & $\mathbf{X}$ \\
\hline 24. Felipe se enamora de Ricomana, hija del rey de Sicilia & $\mathbf{X}$ & $\mathbf{X}$ & $\mathbf{X}$ & & $\mathbf{X}$ & $\mathbf{X}$ & $\mathbf{X}$ \\
\hline 25. Por medio de Tirant, Ricomana acepta a Felipe & $\mathbf{X}$ & & & $\mathbf{X}$ & & $\mathbf{X}$ & $\mathbf{X}$ \\
\hline 26. Tirant y Felipe se embarcan con el rey de Sicilia & & & $\mathbf{X}$ & & & & $\mathbf{X}$ \\
\hline 27. Un marinero incendia las naves de los genovesos & & $\mathbf{X}$ & $\mathbf{X}$ & & $\mathbf{X}$ & $\mathbf{X}$ & $\mathbf{X}$ \\
\hline 28. Rodas es liberada & & & & $\mathbf{X}$ & $\mathbf{X}$ & & $\mathbf{X}$ \\
\hline 29. Ricomana prueba la inteligencia de Felipe & & $\mathbf{X}$ & $\mathbf{X}$ & & $\mathbf{X}$ & $\mathbf{X}$ & $\mathbf{X}$ \\
\hline $\begin{array}{l}\text { 30. Tirant, después de rescatar muchos cristianos, regresa } \\
\text { a Sicilia }\end{array}$ & & & & & & \\
\hline 31. Bodas de Felipe y Ricomana & & & & $\mathbf{X}$ & $\mathbf{X}$ & & \\
\hline $\begin{array}{l}\text { 32. Tirant acompaña a los reyes de Sicilia y de Francia en } \\
\text { una expedición contra los musulmanes }\end{array}$ & & & & & & & \\
\hline 33. Toman la ciudad de Túnez y regresan a Palermo & & & & & & & \\
\hline 34. Tirant regresa a Bretaña & & & & & & & \\
\hline 35. El rey de Sicilia reclama a Tirant & & & & & & & \\
\hline
\end{tabular}

Tirant en el imperio griego (capítulos 115 al 296)

\begin{tabular}{|l|l|l|l|l|l|l|l|}
\hline $\begin{array}{l}\text { 36. El emperador de Constantinopla pide auxilio al rey de } \\
\text { Sicilia }\end{array}$ & & & $\mathbf{X}$ & & $\mathbf{X}$ & $\mathbf{X}$ & \\
\hline $\begin{array}{l}\text { 37. El Sultán y el Gran Turco se han apoderado de parte } \\
\text { de Grecia }\end{array}$ & $\mathbf{X}$ & $\mathbf{X}$ & $\mathbf{X}$ & & & & $\mathbf{X}$ \\
\hline 38. Se recurre a Tirant para expulsar a los infieles & $\mathbf{X}$ & & $\mathbf{X}$ & & & $\mathbf{X}$ & $\mathbf{X}$ \\
\hline 39. Tirant llega a Constantinopla & $\mathbf{X}$ & & & $\mathbf{X}$ & $\mathbf{X}$ & $\mathbf{X}$ & \\
\hline $\begin{array}{l}\text { 40. Lo nombran capitán de los ejércitos y de la justicia } \\
\text { imperiales }\end{array}$ & $\mathbf{X}$ & $\mathbf{X}$ & $\mathbf{X}$ & & $\mathbf{X}$ & $\mathbf{X}$ & $\mathbf{X}$ \\
\hline
\end{tabular}




\begin{tabular}{|c|c|c|c|c|c|c|c|}
\hline 41. El amor por Carmesina sume a Tirant en la melancolía & $\mathbf{X}$ & $\mathbf{X}$ & $\mathbf{X}$ & $\mathbf{X}$ & $\mathbf{X}$ & $\mathbf{X}$ & $\mathbf{X}$ \\
\hline 42. Plaerdemavida tercerea entre Tirant y Carmesina & $\mathbf{X}$ & & & & & & \\
\hline 43. Tirant como estratega & $\mathbf{X}$ & & & & & $\mathbf{X}$ & $\mathbf{X}$ \\
\hline 44. Carmesina también se enamora de él & $\mathbf{X}$ & & & & & & $\mathbf{X}$ \\
\hline \multicolumn{8}{|l|}{ 45. Carmesina defiende a Tirant de cortesanos envidiosos } \\
\hline $\begin{array}{l}\text { 46. Carmesina advierte a Tirant de la maldad del duque } \\
\text { de Macedonia }\end{array}$ & & & $\mathbf{x}$ & & & $\mathbf{X}$ & $\mathbf{X}$ \\
\hline $\begin{array}{l}\text { 47. Tirant declara su amor a la princesa mediante un } \\
\text { espejo }\end{array}$ & $\mathbf{X}$ & $\mathbf{X}$ & $\mathbf{X}$ & & $\mathbf{X}$ & $\mathbf{X}$ & $\mathbf{X}$ \\
\hline 48. Episodio de la yeguada & & & $\mathbf{X}$ & & $\mathbf{X}$ & $\mathbf{X}$ & $\mathbf{X}$ \\
\hline 49. Complejas relaciones entre los dos amantes & $\mathbf{X}$ & & & & & & $\mathbf{X}$ \\
\hline 50. La Viuda Reposada pretende a Tirant & $\mathbf{X}$ & $\mathbf{X}$ & & $\mathbf{X}$ & & $\mathbf{X}$ & $\mathbf{X}$ \\
\hline 51. Estefania forma pareja paralela con Diafebus & $\mathbf{X}$ & & $\mathbf{X}$ & $\mathbf{X}$ & & $\mathbf{X}$ & $\mathbf{X}$ \\
\hline 52. Carmesina es ayudada por Plaerdemavida & & $\mathbf{X}$ & $\mathbf{X}$ & $\mathbf{X}$ & & & $\mathbf{X}$ \\
\hline \multicolumn{8}{|l|}{ 53. Nueva ofensiva del sultán contra Constantinopla } \\
\hline 54. Tirant en el castillo de Malveí & $\mathbf{X}$ & & & & & & \\
\hline $\begin{array}{l}\text { 55. Fingirá que huye para sorprender a los enemigos del } \\
\text { imperio }\end{array}$ & $\mathbf{X}$ & & $\mathbf{X}$ & & & & \\
\hline 56. El duque de Macedonia traiciona a Tirant & $\mathbf{X}$ & $\mathbf{X}$ & $\mathbf{X}$ & & & $\mathbf{X}$ & $\mathbf{X}$ \\
\hline 57. Tirant obtiene una nueva victoria sobre los musulmanes & & & & & & & $\mathbf{X}$ \\
\hline \multicolumn{8}{|l|}{ 58. Tirant envía el botín y los prisioneros a Constantinopla } \\
\hline $\begin{array}{l}\text { 59. El duque de Macedonia no reconoce la autoridad de } \\
\text { Tirant }\end{array}$ & & & & & & $\mathbf{X}$ & \\
\hline \multicolumn{8}{|l|}{ 60. Tirant renuncia a su título de capitán } \\
\hline \multicolumn{8}{|l|}{ 61. Los caballeros condenan la conducta del duque } \\
\hline 62. Felipe, rey de Sicilia, auxilia a Tirant con un ejército & & & & & & $\mathbf{X}$ & \\
\hline \multicolumn{8}{|l|}{$\begin{array}{l}\text { 63. El emperador se suma para llegar al lugar de los } \\
\text { combates }\end{array}$} \\
\hline $\begin{array}{l}\text { 64. Carmesina al frente de un ejercito femenino se } \\
\text { incorpora a la expedición }\end{array}$ & $\mathbf{X}$ & & & & & & \\
\hline \multicolumn{8}{|l|}{ 65. El duque de Macedonia intenta matar a Tirant } \\
\hline $\begin{array}{l}\text { 66. El duque de Macedonia muere a manos del rey de } \\
\text { África }\end{array}$ & & & & & & & \\
\hline
\end{tabular}




\begin{tabular}{|c|c|c|c|c|c|c|}
\hline 67. Tirant vence por su estrategia y coraje & & & & & & \\
\hline $\begin{array}{l}\text { 68. Juegos galantes entre Estefanía-Diafebus y Tirant- } \\
\text { Carmesina }\end{array}$ & & & & & & $\mathbf{X}$ \\
\hline 69. Diafebus obtiene el título de conde de Sant Àngel & & & & & & $\mathbf{X}$ \\
\hline 70. Tirant y Diafebus se encuentran con sus amadas & & & & $\mathbf{X}$ & & $\mathbf{X}$ \\
\hline $\begin{array}{l}\text { 71. Plaerdemavida cuenta la escena y declara su pasión } \\
\text { por Hipólito }\end{array}$ & $\mathbf{X}$ & & & & & \\
\hline $\begin{array}{l}\text { 72. Tirant sale victorioso de los combates con los } \\
\text { enemigos del imperio }\end{array}$ & & & & & & $\mathbf{X}$ \\
\hline $\begin{array}{l}\text { 73. El Vizconde Branches llega a Constantinopla con las } \\
\text { galeras }\end{array}$ & & & & & & \\
\hline $\begin{array}{l}\text { 74. Tirant pide al emperador la mano de Estefania para } \\
\text { Diafebus }\end{array}$ & & & & & & \\
\hline 75. Diafebus se convierte en duque de Macedonia & & & & & $\mathbf{X}$ & \\
\hline $\begin{array}{l}\text { 76. Estefania se propone favorecer los amores de Tirant y } \\
\text { Carmesina }\end{array}$ & & & & & & \\
\hline $\begin{array}{l}\text { 77. La Viuda Reposada se opone a los amores de Tirant y } \\
\text { Carmesina }\end{array}$ & $\mathbf{X}$ & & & & $\mathbf{X}$ & $\mathbf{X}$ \\
\hline $\begin{array}{l}\text { 78. Plaerdemavida logra entrar al héroe en la cámara de } \\
\text { Carmesina }\end{array}$ & $\mathbf{X}$ & & $\mathbf{X}$ & & $\mathbf{X}$ & $\mathbf{X}$ \\
\hline 79. Tirant, escondido, contempla la desnudez de su amada & & $\mathbf{X}$ & & & $\mathbf{X}$ & $\mathbf{X}$ \\
\hline $\begin{array}{l}\text { 80. Los celos de la Viuda Reposada despiertan a todo } \\
\text { palacio }\end{array}$ & & & $\mathbf{X}$ & & $\mathbf{X}$ & $\mathbf{X}$ \\
\hline 81. Tirant huye por una ventana rompiéndose una pierna & & & $\mathbf{X}$ & $\mathbf{X}$ & & $\mathbf{X}$ \\
\hline $\begin{array}{l}\text { 82. La Viuda Reposada hace creer a la princesa que Tirant } \\
\text { la difama }\end{array}$ & $\mathbf{X}$ & & & & & \\
\hline $\begin{array}{l}\text { 83. La Viuda Reposada convence a Tirant, que Carmesina } \\
\text { ama a Lauseta }\end{array}$ & $\mathbf{X}$ & $\mathbf{X}$ & $\mathbf{X}$ & & $\mathbf{X}$ & $\mathbf{X}$ \\
\hline 84. La emperatriz descubre que Hipòlito la ama & & & & & & $\mathbf{X}$ \\
\hline $\begin{array}{l}\text { 85. La emperatriz retiene a Hipólito en contra de su } \\
\text { voluntad }\end{array}$ & & & & & & $\mathbf{X}$ \\
\hline 86. Tirant se recupera de las graves molestias de su salud & & & & & & \\
\hline $\begin{array}{l}\text { 87. Diafebus cae prisionero en una batalla en la que los } \\
\text { turcos obtienen una gran victoria }\end{array}$ & & & & & & \\
\hline
\end{tabular}




\begin{tabular}{|l|l|l|l|l|l|l|l|}
\hline $\begin{array}{l}\text { 88. Plaerdemavida explica a Tirant la perfidia de la Viuda } \\
\text { Reposada }\end{array}$ & $\mathbf{X}$ & $\mathbf{X}$ & & & & $\mathbf{X}$ \\
\hline
\end{tabular}

Tirant en el Norte de África (capítulos 297 al 413)

\begin{tabular}{|l|l|l|l|l|l|l|l|}
\hline 89. Tirant y Plaerdemavida se entrevistan en un barco & $\mathbf{X}$ & $\mathbf{X}$ & $\mathbf{X}$ & & $\mathbf{X}$ & $\mathbf{X}$ & $\mathbf{X}$ \\
\hline $\begin{array}{l}\text { 90. Se desata un temporal que los lleva a las costas de } \\
\text { Berbería }\end{array}$ & $\mathbf{X}$ & $\mathbf{X}$ & $\mathbf{X}$ & $\mathbf{X}$ & $\mathbf{X}$ \\
\hline 91. Tirant y Plaerdemavida se salvan independientemente & $\mathbf{X}$ & $\mathbf{X}$ & $\mathbf{X}$ & & & $\mathbf{X}$ & $\mathbf{X}$ \\
\hline 92. La doncella es recogida por un moro viejo & & & $\mathbf{X}$ & & & $\mathbf{X}$ & $\mathbf{X}$ \\
\hline 93. Tirant es recogido por un dignatario moro & $\mathbf{X}$ & $\mathbf{X}$ & $\mathbf{X}$ & & & $\mathbf{X}$ & $\mathbf{X}$ \\
\hline 94. Escariano y Tremicén entran en conflicto & & & & & & $\mathbf{X}$ & \\
\hline 95. Tirant libera a Maragdina y a su padre & $\mathbf{X}$ & & & & $\mathbf{X}$ \\
\hline 96. Estratagema del cautivo albanés & $\mathbf{X}$ & & & & $\mathbf{X}$ \\
\hline 97. Tirant bautiza a Maragdina y Escariano, que se casan & $\mathbf{X}$ & & & & $\mathbf{X}$ & $\mathbf{X}$ \\
\hline 98. Con la ayuda de un fraile, bautiza a 4000 musulmanes & $\mathbf{X}$ & & & & $\mathbf{X}$ & $\mathbf{X}$ \\
\hline 99. Tirant encuentra y reconoce a Plaerdemavida & $\mathbf{X}$ & & & & $\mathbf{X}$ & $\mathbf{X}$ \\
\hline 100.Plaerdemavida y el señor d'Agramunt se casan & & $\mathbf{X}$ & $\mathbf{X}$ & & $\mathbf{X}$ & $\mathbf{X}$ \\
\hline 101. Tirant envía un emisario a Constantinopla & & & & & & & \\
\hline $\begin{array}{l}\text { 102. Tirant es reclamado, ya que los turcos llegan casi a la } \\
\text { capital del imperio }\end{array}$ & & & & & \\
\hline
\end{tabular}

Liberación del Imperio Griego y muerte de Tirant (capítulos 414 al 487)

\begin{tabular}{|c|c|c|c|c|}
\hline $\begin{array}{l}\text { 103. Tirant, demanda dos ejércitos uno al rey de Etiopía y } \\
\text { otro a Felipe rey de Sicilia, con el fin de combatir por } \\
\text { el imperio griego }\end{array}$ & & & $\mathbf{X}$ & \\
\hline $\begin{array}{l}\text { 104. Tirant desembarca en Troya y anuncia al emperador } \\
\text { su llegada inminente }\end{array}$ & & $\mathbf{X}$ & & $\mathbf{X}$ \\
\hline \multicolumn{5}{|l|}{ 105.Hipólito defiende el sitio de Constantinopla } \\
\hline 106.La Viuda Reposada se suicida & & & $\mathbf{X}$ & \\
\hline \multicolumn{5}{|l|}{ 107.Tirant logra rendir a los enemigos } \\
\hline \multicolumn{5}{|l|}{$\begin{array}{l}\text { 108. Tirant entra de incógnito en la ciudad y encuentra a } \\
\text { Plaerdemavida }\end{array}$} \\
\hline 109.Bodas sordas de Tirant y Carmesina & $\mathbf{X}$ & & $\mathbf{X}$ & $\mathbf{X}$ \\
\hline $\begin{array}{l}\text { 110.Después de entrevistarse con el emperador, se firma la } \\
\text { paz }\end{array}$ & & & $\mathbf{X}$ & $\mathbf{X}$ \\
\hline
\end{tabular}




\begin{tabular}{|l|l|l|l|l|l|l|l|}
\hline $\begin{array}{l}\text { 111.Tirant regresa al campamento y entra triunfal en } \\
\text { Constantinopla }\end{array}$ & & & & & & & \\
\hline 112.El emperador le ofrece la mano de su hija Carmesina & $\mathbf{X}$ & $\mathbf{X}$ & $\mathbf{X}$ & & $\mathbf{X}$ & $\mathbf{X}$ & $\mathbf{X}$ \\
\hline 113.Tirant César del imperio griego & & & & & & & \\
\hline 114.Tirant recupera ciudades perdidas y libera a Diafebus & $\mathbf{X}$ & $\mathbf{X}$ & & & & & $\mathbf{X}$ \\
\hline 115.Paseando por la orilla de un río enferma & $\mathbf{X}$ & $\mathbf{X}$ & $\mathbf{X}$ & & $\mathbf{X}$ & $\mathbf{X}$ & $\mathbf{X}$ \\
\hline 116.Otorga testamento & $\mathbf{X}$ & $\mathbf{X}$ & $\mathbf{X}$ & & & $\mathbf{X}$ & $\mathbf{X}$ \\
\hline $\begin{array}{l}\text { 117.Muere camino de su hogar } \\
\text { 118.Carmesina muere de pena }\end{array}$ & $\mathbf{X}$ & $\mathbf{X}$ & $\mathbf{X}$ & $\mathbf{X}$ & & $\mathbf{X}$ & $\mathbf{X}$ \\
\hline 119.El emperador también muere & $\mathbf{X}$ & $\mathbf{X}$ & $\mathbf{X}$ & $\mathbf{X}$ & $\mathbf{X}$ & $\mathbf{X}$ & $\mathbf{X}$ \\
\hline $\begin{array}{l}\text { 120.La emperatriz heredera del imperio se casa con } \\
\text { Hipólito }\end{array}$ & & $\mathbf{X}$ & $\mathbf{X}$ & & & & $\mathbf{X}$ \\
\hline $\begin{array}{l}\text { 121.Los despojos de Tirant y de Carmesina son } \\
\text { transportados a Bretaña }\end{array}$ & & & & & & & $\mathbf{X}$ \\
\hline 122.Muere la emperatriz & & $\mathbf{X}$ & & & & & $\mathbf{X}$ \\
\hline 123.Hipólito se casa en segundas nupcias & & $\mathbf{X}$ & $\mathbf{X}$ & & & & $\mathbf{X}$ \\
\hline 124.Epitafio de Tirant i Carmesina & $\mathbf{X}$ & $\mathbf{X}$ & & & $\mathbf{X}$ & $\mathbf{X}$ & $\mathbf{X}$ \\
\hline
\end{tabular}

Se observa en la tabla que la mayor parte de las secuencias elegidas por los adaptadores coinciden en tres partes de la novela de Martorell: Tirant en el norte de África, es la más seleccionada, juntamente con Tirant en el imperio Griego. Evidentemente todos coinciden de nuevo en seleccionar el amor de Tirant y Carmesina y la muerte de ambos.

Se ha comprobado que en todas las adaptaciones aparecen unos pasajes, de relativa importancia en el conjunto de la obra y que no añaden significación especial a la selección, pero que por su alta densidad literaria no podían obviarse, ya que son, por su singularidad, fácilmente recordables y pueden promover la lectura del hipotexto verbal. Así, por ejemplo, vemos como la lucha de Tirant con el alano, o la blancura de la piel de la hija del rey de Francia que transparentaba el vino a su paso por la garganta, son episodios que no faltan en ninguna selección.

Muchos han sugerido, arteramente, que el salto de Tirant lo Blanc a la literatura universal vino de la mano del manco de Lepanto. No sabemos la intención de Miguel de Cervantes en el escrutinio que, sobre la biblioteca de Alonso Quijano, realizara el cura, mientras ama y sobrina del hidalgo caballero lanzaban impávidamente al fuego libro tras libro, pero después de un análisis pormenorizado de las diferentes adaptaciones LIJ de Tirant lo Blanc se podría afirmar que las palabras de Pedro Pérez han servido de pauta a muchos de los adaptadores de la obra de Martorell. La archiconocida cita cervantina dice así: 
'- ¡Válame Dios! - dijo el cura, dando una gran voz - ¡Qué aquí esté Tirante el Blanco! Dádmele acá, compadre; que hago cuenta que he hallado en él un tesoro de contento y una mina de pasatiempos. Aquí está don Quirieleisón de Montalbán, valeroso caballero, y su hermano Tomas de Montalbán, y el caballero Fonseca, con la batalla que el valiente de Tirante hizo con el alano, y las agudezas de la doncella Placerdemivida, con los amores y embustes de la viuda Reposada, y la señora Emperatriz, enamorada de Hipólito, su escudero. Dígoos verdad, señor compadre, que, por su estilo, es éste el mejor libro del mundo: aquí comen los caballeros, y duermen y mueren en sus camas, y hacen testamento antes de su muerte, con estas cosas que todos los demás libros de deste género carecen...' (CERVANTES, 2000, p.134)

Además, partiendo cada adaptador de sus propios criterios, todos ellos han confluido en un mismo grupo de proposiciones. Se han marcado en cursiva las proposiciones coincidentes con la conocida cita del Quijote:

1. Tirant lo Blanc conoce al ermitaño

2. El ermitaño le explica el Orden de Caballería

3. Tirant, armado caballero, sale vencedor de numerosos combates

4. La bella Agnès da su broche en prenda

5. Combate con el señor de las Vilesermes

6. Tirant combate con tres reyes

7. Combate con el alano

8. Tirant retado por Kirieleison de Muntalbà

9. El infante Felipe, fill del rey de Francia, se adhiere a la causa

10. Un marinero incendia las naves de los genovesos

11. Ricomana prueba la inteligencia de Felipe

12. El Sultán y el Gran Turco se han apoderado de parte de Grecia

13. Lo nombran capitán de los ejércitos i de la justicia imperiales

14. El amor por Carmesina lo sume en la melancolía

15. Tirant declara su amor a la princesa mediante un espejo

16. La Viuda Reposada pretende a Tirant

17. Estefania forma pareja paralela con Diafebus

18. Carmesina es ayudada por Plaerdemavida

19. El duque de Macedonia traiciona a Tirant

20. Plaerdemavida logra entrar al héroe en la cámara de Carmesina

21. La Viuda Reposada convence a Tirant, que Carmesina ama a Lauseta

22. Tirant y Plaerdemavida se entrevistan en un barco

23. Se desata un temporal que los lleva a las costas de Berbería

24. Plaerdemavida y el señor d'Agramunt se casan

25. Bodas sordas de Tirant y Carmesina

26. El emperador le ofrece la mano de su hija Carmesina

27. Paseando por la orilla de un río enferma

28. Otorga testamento 
29. Muere camino de su hogar

30. Carmesina muere de pena

31. El emperador también muere

32. Epitafio de Tirant i Carmesina

Los intereses de cada adaptación han provocado divergencias en la selección de la información. La llevada a término por Abad es mínima ya que su obra, a tenor de las ilustraciones, fue pensada para un público neolector. En cambio, el registro lingüístico apunta lectores con mayor pericia.

La adaptación de Navarro parece guiada por otros criterios: busca contar la historia en su conjunto, de hecho la selección es certera, estimulando la curiosidad del lector para enfrentarse con la versión original. El léxico, la extensión de la obra y el ritmo de los capítulos podrían situar esta adaptación en una franja de receptores infantiles, de 9 a 12 años, con autonomía lectora.

La selección operada por Franco elige aquellos pasajes esenciales de las cinco grandes y los une de manera acumulativa. Tanto el ritmo de la narración como el registro lingüístico empleados apuntan a un receptor juvenil.

Miralles centra su interés en Tirant en Sicilia y Rodas y Tirant en el Norte de África. En cambio selecciona pocas secuencias de Tirant en el imperio Griego y la parte final de Tirant.

El grupo formado por Sales, Capmany y Torres elige una mayor cantidad de secuencias. Estas tres ediciones presentan coincidencias tanto por la selección de la información —en todas ellas se conserva la esencia del hipotexto - como por el número de páginas cuya extensión parece dirigida a un público juvenil. El registro lingüístico marca diferencias entre ellas. Tanto el léxico como la sintaxis elegidos por Torres son adecuados al lector juvenil actual. En cambio, Sales y Capmany, tal vez guiados por la intención de mejorar la formación lingüística y estética de sus receptores, optaron por un registro superior al de los lectores juveniles actuales.

\section{Conclusiones}

La mayoría de los adaptadores han tenido en consideración los pasajes mencionados en la valoración que de Tirant lo Blanc hiciera Cervantes en El ingenioso Hidalgo don Quijote de la Mancha. Se ha comprobado, una vez más, el oportunismo del negocio editorial con la publicación de diferentes adaptaciones aprovechando que en 2006 se celebró el IV centenario de la publicación del Quijote.

Con la finalidad de acelerar el ritmo, las adaptaciones LIJ optan por centrarse en la acción, restringiendo al máximo las secuencias descriptivas, frecuentemente reducidas a escasos adjetivos. En muchas ocasiones, las ilustraciones tratan de suplir elementos descriptivos aunque no siempre se consigue. La presencia de imágenes es inversamente proporcional estadio de formación estética y lingüística del receptor, a mayor autonomía lectora, menor presencia icónica. Los criterios de 
venta también influyen en las ilustraciones de las ediciones preparadas para jóvenes. En todas ellas aparece alguna ilustración que crea falsas expectativas sobre la realidad poliédrica de la novela.

Algunas ediciones, por sus sugerencias, contienen en germen la lectura adulta e inteligente del original, en cambio otras agotan en sí mismas las posibilidades de posteriores lecturas. Las adaptaciones confirman que Tirant lo Blanc es una obra compleja que sólo puede ser saboreada por lectores adultos en ediciones debidamente anotadas. 


\section{Bibliografía}

Cervantes, M. de. (2000) El Ingenioso Hidalgo Don Quijote de La Mancha, 2 vols., Madrid, Cátedra.

Duran, T. (2009) «Eines per a l’anàlisi de la il lustració», Caplletra, 46, pp. 219-236

Estébanez, D. (1996) Diccionario de términos literarios, Madrid, Alianza.

Genette, G. (1989) Palimpsestos: La literatura en segundo grado, Celia Fernández Prieto (trad.), Madrid, Taurus.

Hutcheon, L (2006) A Theory of Adaptation, New York \& London, Routlege.

Lluch, G. (2003) Análisis de narrativas infantiles y juveniles, Cuenca, Ediciones de la Universidad de CastillaLa Mancha.

Lluch, G. (2009) «Dades per a l'anàlisi de narratives per al lector infantil i juvenil», Caplletra, 46, pp. 121-148.

Martorell, J. (1979) Tirant el Blanc. Adaptació per a nois i noies, Joan Sales (adapt.); Ferran Solde vila (prol.); Elvira Elías (ilustr.), Barcelona, Edicions del Mall.

_. (1989) Tirant lo Blanc, Maria Aurèlia Capmany (adapt.); Manuel Boix (ilustr), Barcelona, Edicions Proa.

—. (1998) Tirant lo Blanc, Maria Aurèlia Capmany (adapt.), Barcelona, La Galera.

- (2005) Tirant lo Blanc contat als infants, Rosa Navarro Durán (adapt.), Bruno Gómez y Pau Joan Hernàndez (trad.), Francesc Rovira (ilustr.), Mislata, Marjal.

—.(2005) Tirant lo Blanc explicat als infants, Rosa Navarro Durán (adapt.), Pau Joan Hernàndez (trad.), Francesc Rovira (ilustr.), Barcelona, Edebé.

—. (2006) Tirant lo Blanc, Mònica Abad (adapt.), Montse Ginesta (ilustr.), Barcelona, Susaeta.

. (2006) Tirant lo Blanch de Joanot Martorell, José Vicente Miralles Piles (adapt.), Enrique Climent Llopis (ilustr.), Valencia, L’Oronella.

—. (2008) Tirant lo Blanc, Ismael Torres (adapt.), Albert Hauf (pról.), Jesús Gabán (ilustr.), València, Vicens Vives.

—. (2008) Tirant lo Blanc, Albert Hauf (ed.), Valencia, Tirant lo Blanc.

Martorell, Joan \& de Galba, Martí Joan (2006) Tirant lo Blanc, Josep Franco (adapt.), Enric Solbes (ilustr.), Alzira, Edicions Bromera.

Mata, J. (2009) 10 ideas clave. Animación a la lectura: hacer de la lectura una práctica feliæz, tascendente y deseable, Barcelona, Graó.

Navarro, R. (2006) «Los clásicos al alcance de los niños», CLIJ nº 193.

Soriano, M. (1995) La literatura para niños y jóvenes: Guia de exploración de sus grandes temas; Traducción, adaptación y notas de Graciela Montes, Buenos Aires, Colihue. 